\title{
The Analysis of Code-switching Integration Realization on Students Classroom Performance
}

\author{
Lamhot Naibaho $^{1 *}$, Bernadetha Nadeak ${ }^{2}$, Elferida Sormin ${ }^{3}$, Citra Puspa Juwita ${ }^{4}$ \\ ${ }^{1,3}$ Departement of English Education, Universitas Kristen Indonesia, Jakarta, Indonesia \\ ${ }^{2}$ Magister of Education Administration, Universitas Kristen Indonesia, Jakarta, Indonesia \\ ${ }^{4}$ Faculty of Vocation, Universitas Kristen Indonesia, Jakarta, Indonesia \\ lnaibaho68@gmail.com ${ }^{1}$, benabeni336@gmail.com ${ }^{2}$,elferida.sormin@uki.ac.id ${ }^{3}$, citra.simatupang@uki.ac.id ${ }^{4}$ \\ Corresponding Author: lamhot.naibaho@uki.ac.id
}

\begin{abstract}
This research is about the analysis of Code-switching integration realization on students' classroom performance. It is done to find out how the integration of Code-switching realization on students' classroom performance. It was done at Universitas Kristen Indonesia. The research method used was a qualitative research approach with a descriptive design. The subject of the research was the student of batch 2017 in English for Basic Math class. The instruments used were observation sheets and documentation. The findings of the research are: a) there are three types of Codeswitching used by the students during classroom performances, are: 1) there were 78 utterances that belong to Codeswitching (inter-sentential); 2) 64 utterances that belong to Code-switching (intra-sentential), and 3 ) 45 utterances that belong to Code-switching (tag-switching); b) there were five functions of Code-switching found during the classroom performances, they are: reiterations function 28 (15\%), addressee specifications function 52 (28\%), quotations function $46(25 \%)$, and personalization $37(20 \%)$, and message qualification function $24(12 \%)$. The conclusion is that the students of the English Education Department batch 2017 still made a lot of Code-switching during the classroom performances, where it indicates that the students' ability in speaking requires improvement, especially in a specific field such as Mathematics.
\end{abstract}

\section{Keywords: Code-switching, Realization, Classroom Performance, Analysis}

\section{INTRODUCTION}

Language is an agreement between language users or knowing the code agreed to be used in communication (Naibaho, 2019). Language is an essential aspect of human life (Naibaho, 2019; Terrell and Brown, 1981). With language, the community can carry out communication, interaction, and interconnection among members. So that for everyday needs, humans need a media called language. Therefore, every society is ensured to have and use language as a means of social communication (Naibaho, 2016a, 2016b). So that society and language cannot be separated. No society does not have a language, and there is no language without a community that uses it. From this, it can be understood that language is a communication tool used by humans in everyday life because human language can interact with others to find out the information-information needed. Language emerges and develops due to interactions between individuals in a society (Hlavac, 2011).
Linguistics focuses on the proper explanation of parts of language such as sound, syllable, words, sentences, and language (Aitchison and Wardaugh, 1987; Clark and Yallop, 2006; Salzmann, 2003; Iqbal, 2011). In further developments, linguistics also has several branches of science. It happens because it intersects with other sciences. Some branches of linguistics include (1) psycholinguistics is a science formed due to the combination of linguistics with psychology, where this science focuses on human language and psychology of someone who studies or uses the language, (2) sociolinguistics, which is a combination of sociology which means the social life of the language user community with linguistics or the language of the community itself (Sampson, 2012; Scotton, 2010; Scotton and Ury, 1977). Besides, linguistics can also be classified based on its primary purpose is pure linguistics and applied linguistics. Pure linguistics studies language, in general, to describe language to obtain a description of aspects of language such as phonology, morphology, syntax, and semantics. At the same time, applied linguistics is considered a science that tries to apply linguistics principles for 
practical purposes. Applied linguistics is used in teaching and learning terms (Aitchison and Wardaugh, 1987). Code-switching is an act of entering words, phrases, or parts of conversations that are longer into other languages (Balukas and Koops, 2015; Terrell and Brown, 1981). This phenomenon is the basis for researchers to research Code-switching to find problems that occur in more detail.

Code is a term that can refer to language, dialect, sociolect, or various languages (González-Vilbazo et al., 2015). A code is a sign that is used in a language with a specific purpose. Code-switching often occurs in the communication of someone who still does not master the language being used. Code-switching occurs following the community's conditions (Aitchison and Wardaugh, 1987; Dewaele and McCloskey, 2015). Code-switching can occur when a speaker uses a language, and his partner answers in another language. It is in line with previous research, which says that in this case, the speaker changes the elements of other languages when using specific languages (Cacoullos and Travis, 2011; Richards and Schmidt, 2010). The other factor which is the basis of this research is because Indonesian people who are generally bilingual or multilingual communities are people who have several sample languages (L1) are native languages, (L2) are Indonesian and are added with (L3), namely languages foreign both English and other languages. The use of two or more languages in communication events is a common phenomenon in Indonesia. It was said so because the people involved in the act of communication at least mastered more than one language, for example, regional languages (Javanese, Bataknese, Amboness, Papuanese, Balinese), first language (Indonesian), and foreign languages (English, Mandarin, and Tagalog).

As a result of the bilingual situation in the learning process of UKI students in the English language education study program, there are determinants in decision making in a speech. Besides, the presence of language contact in the class also causes code-switching symptoms to the speakers. In other words, the language phenomenon (Code-switching) refers to events where, when speaking, many students enter elements of other languages into the language they are using, namely English. This phenomenon occurs in the learning process in class and when students are conversing in English in the English Education Program environment and when students take a series of final assignment exams both proposal seminars and thesis exams. The English education study department is one of the Departments at UKI that focuses on English, one of the international languages. The study program aims to produce capable and skilled students in communicating using English so that the graduates produced can use English effectively. Therefore, one of the subjects considered to shape and hone the English communication skills of UKI students is speaking for academic presentation. In general, teaching this course is for students to be able to use the language actively and professionally.

\section{LITERATURE REVIEW}

Code-switching as a symptom of language use transition due to changing circumstances. Codeswitching occurs between languages. Code-switching does not only occur between languages but also between types of styles that exist in one language. For example, between relaxed variety and official variety. Code-switching has become a common term for alternate languages for two languages, varieties of language, or even speech styles. Code-switching tends not to require much effort to switch codes. Bilingual speakers are often involved in what seems to be an "effortless switch" between the two languages they speak. This transition can occur in conversation when there is an exchange of registers caused by background, interlocutors, purpose of conversation and other social factors. Code transfer is done consciously and uncaused, and Code-switching can occur at the level of words, phrases and sentences (Isurin et al., 2009; Zabrodskaja, 2011).

Sociolinguistics have discovered many factors that cause Code-switching. That factor is related to the principal linguistic issues that are consistent with what Fishman put forward, namely: a) who speaks, b) in what language, c) to whom, d) when, and e) for what purpose. In various literature on Code-switching, we can find the causes of Code-switching as follows: a) speaker or speaker; b) the listener or interlocutor; c) changes in the situation with the presence of a third person; d) change from formal to informal or vice versa; and e) change in subject. On the one hand, Codeswitching usually occurs because of the speaker's initiation (Kamisah Ariffin and Misyana Susanti Husin, 2011; Lin, 2013). A speaker switches codes frequently for benefits or benefits, for example, a sense of similarity or familiarity. On the other hand, it is the interlocutor or interlocutor who causes Code-switching, for example, because the person concerned wants to compensate for the opponent's language abilities. In this case, the opponent's speaking ability is usually lacking or somewhat lacking because it is not his first language.

The forms and variants in Code-switching can be the cause. If the interlocutor has the same language background as the speaker, Code-switching will only 
take the form of a transitional variant (both regional and social), variety, style or register (Gort, 2012; Musk, 2010). If the language background is different, then what happens is the transfer, For example, a salesperson of a souvenir shop, the arrival of a foreign tourist who invites conversation in Indonesian. When the tourist seems to be at a loss for words to continue conversing in Indonesian, Ani immediately switches the code to English so that the conversation will resume smoothly. In addition to the five things above, there are still causes of Code-switching related to the verbal repertoire found in the speech community and how the speaker's social status on the languages or the variety of languages contained in the speech community.

\section{METHOD}

This research is qualitative research with a descriptive design that aims to expose the phenomena that occur (Creswell, 2012, 2009). The study of the language used in students' classroom performances during conduction presentation on English for Basic Math course, where the students have to use English during the presentation. This study explains how students use code-mixing in their classroom performances. Data collected through observation (Brennen, 2018; Crozier et al., 1994; Henderson, 2011). Hatch says that observation is collecting data to understand the culture, places, social phenomena that occur through the participant's view. Besides the observation sheet, the data was collected through an audio recorder. The data collection process is done through several methods to maintain data validity.

The step is also carried out to obtain the desired data in research (Creswell, 2009). The subjects of this research are the English Education Department students batch 2017. The number of students was 22 students. In qualitative research, there are several steps in analyzing data. In this study, researchers focus on the steps suggested by Miles and Huberman (Creswell, 2012). The several steps involved in qualitative research are researchers must prepare and arrange data to be analyzed (Creswell, 2009). First, data reduction. The steps are taken in this stage are selecting, focusing and simplifying which data will be taken in research. In this stage, data coding is also performed. Coding is the stage in analyzing data by category (Richards and Schmidt, 2010). Second, the presentation of data (data display), in this stage, the data that has been collected is grouped into several sections according to the type of category of data obtained so that it is easily seen, understood and analyzed so that researchers can draw appropriate conclusions from the results of the research. The third stage, namely the conclusion or verification (conclusion drawing or verification). As a final step, the data are analyzed based on students' data during the research process.

\section{RESULT AND DISCUSSION}

This research was conducted during the teaching and learning process of speaking for academic presentation to find out the types of Code-switching and its benefits. The results of this study indicate that there are three types of Code-switching used by students, namely inter-sentential Code-switching, tag switching, and intra-sentential Code-switching. The data above is following the opinion of (Ammon, 2005; Mallinson, 2008; Muldner et al., 2019; Olson, 2012), which states that there are three types of Code-switching usage intersentential, intra-sentential, and tag-switching. This study also found five functions of using Codeswitching, namely quotation, addressee specifications, reiterations, message qualification, and personalization or objectification. Data from the documentation also provides information that supports the research data and is also enriched through observation data carried out four times over 45 minutes with randomized time during the teaching and learning process.

There are several types of Code-switching used by students in the classroom, namely inter-sentential Code-switching, tag switching, and intra-sentential Code-switching (Ahmad and Jusoff, 2009; Modupeola, 2013).

Table 1. Code-switching category

\begin{tabular}{|c|c|c|c|}
\hline No & Category & Number & $\%$ \\
\hline 1 & Inter-sentential & 78 & $42 \%$ \\
\hline 2 & Intra-sentential & 64 & $34 \%$ \\
\hline 3 & Taq-switching & 45 & $24 \%$ \\
\hline \multicolumn{2}{|c|}{ TOTAL } & 187 & $100 \%$ \\
\hline
\end{tabular}

From the table, it is known that during the classroom performances, there were 187 Codeswitching done by the students. They are classified as a) $78(42 \%)$ goes to inter-sentential Code-switching Inter-sentential switching is a process of switching clauses or sentences in one language. Inter-sentential switching often occurs in teaching and learning in the classroom because the speaker uses code-switching because they feel the need to clarify or interpret what was said before. The data analysis results show that inter-sentential switching is one of the most common types, with 78 data out of a total of 187 utterances; b) $64(34 \%)$ goes to intra-sentential Code-switching - 
Someone in communication does this type by diverting words in sentences. In other words, this type of Codeswitching occurs in the speaker's sentence when doing the teaching and learning process. The results showed that 35 data could be categorized as intra-continental switching types; and c) 45 (24\%) goes to taq-switching - The third type of Code-switching is tag switching, where the speaker enters a short word to emphasize the speech. While speaking for academic presentation class, the process that takes place shows that students do this type when they want to convince their conversation by slipping short words. Students enter short words as a sign of emphasis on what they say. The results found 20 data on the use of this type of Code-switching tag.

Substitution between languages tends to depend on fluency and external and internal functions. We can see under what conditions speakers speak the language. In general, this condition is created by three things, namely 1) the topic of conversation, 2) the people involved, and 3) tension. This transfer will also occur in spoken or spoken language. It is evident in the ten topics discussed above. There also appears to be social motivation and social relations in Code-switching, which drives the code's transfer.

Code-switching often seems not realized by the speakers because it does not require significant effort. It is consistent with what is presented by (Isurin et al., 2009). In addition to not demanding meaningful effort, Code-switching can bring closer or distance the distance between speakers. Code-switching in the statements above is due to the ongoing situation, namely the informal situation. It is in line with (Jingxia, 2010) that in everyday life, code-mixing and Code-switching occur a lot, especially in the atmosphere of informal events.

Regarding this situation, (Isurin et al., 2009) explained that research over the past decade shows why people switch codes, but the reasons they do it are not so clear. There is plenty of evidence for common causes such as language fluency, settings requiring interaction, group affiliation, the typological distance between languages and various other factors that influence the global pattern of Code-switching. However, how these general factors are linked to Code-switching remains unclear, and according to (Horasan, 2014; Piccinini and Arvaniti, 2015), this (the presence of every code change and every language switch) is impossible to predict. If we can determine where a code transfer can occur and in a situation where not, there is no way to know in advance when the Code-switching will occur.

The second part of the research data shows that code-switching has its function for the speaker. In other words, the speaker uses Code-switching for specific purposes. The study results indicate that there are five functions of using Code-switching used by English students during the Speaking for Academic presentation class, especially when they are presenting in front of the class. The five functions of using Code-switching are Quotation, Addressee specification, Reiterations, Message qualification, and Personalization or Objectification.

Table 2. Category of Code-switching Function

\begin{tabular}{|c|c|c|c|}
\hline No & Category & Number & $\%$ \\
\hline 1 & Reiterations function & 28 & $15 \%$ \\
\hline 2 & $\begin{array}{c}\text { Addressee } \\
\text { Specifications function }\end{array}$ & 52 & $28 \%$ \\
\hline 3 & Quotations function & 46 & $25 \%$ \\
\hline 4 & $\begin{array}{c}\text { Personalization } \\
\text { function }\end{array}$ & 37 & $20 \%$ \\
\hline 5 & $\begin{array}{c}\text { Message qualifications } \\
\text { function }\end{array}$ & 24 & $12 \%$ \\
\hline \multicolumn{2}{|c|}{ TOTAL } & 187 & $100 \%$ \\
\hline
\end{tabular}

From the above table, it is known that there are five functions of Code-switching found during the class performances. They are classified as follows: a) Reiterations function - The use of Code-switching can occur intentionally and spontaneously when someone is talking or communicating. This type of reiteration occurs when someone repeats what has been said to clarify or put pressure on what information has been said. From the results of the research obtained, 28 (15\%) utterances were included in this function; b) Addressee specifications function - The second function of using Code-switching is the addressee specification. This type aims to give or draw the attention of participants or listeners to what is conveyed by the speaker. Students often do this type when they deliver material in front of the class in speaking for academic presentations. From the above table, it is known that there were $52(28 \%)$ utterances that belong to this function; c) Quotation function - The function of using Code-switching as a quotation is to replace words by using the original language of the quote used or the language in question. In other words, the usefulness of this type is when someone can be bilingual or bilingual, where someone communicates his speech using the original language intended by the speaker. From the above table, it is known that there were 46 (25\%) utterances that belong to this function; d) Personalization functions - the personalization function of Code-switching used by students when making presentations in class is personalization or objectification. Use this function to communicate or convey what is in the speaker's mind about a thing or situation. From the above table, it is known that there were $37(20 \%)$ utterances that belong to this function; and e) Message qualifications functions - The function 
of Code-switching as message qualification aims to limit what is being conveyed by the speaker. The speaker uses Code-switching because they want to convince the listener that the listener understands which information and what part the speaker means. From the above table, it is known that there were 24 (12\%) utterances belong to this function.

From the above elaboration, it is known that the inter-sentential category is the most category used by the students during classroom performances, namely when each group of the students presents the topics of presentation, they kept on doing inter-sentential Codeswitching. There was $78(42 \%)$ time of the whole students made an inter-sentential category. While according to the functions of code-switching, the most function found from the whole classroom performances of the students was addressee specification function, namely there were $52(28 \%)$ utterances that found. It is done to give or draw participants or listeners' attention to what is conveyed by the speaker. This type is also often done by students when they deliver material in front of the class in speaking for academic presentations

\section{CONCLUSION}

This research concludes that there are three types of Code-switching and five functions for using Codeswitching from students' whole classroom performances through a presentation on English for Basic Math class. They are: 1) there were 78 utterances that belong to Code-switching (inter-sentential) - The speaker uses this type to clarify the previous conversation; 2) there were 64 utterances that belong to Code-switching (intrasentential) - This type is used by students in communication where the purpose of using this type is to limit the sentences; and 3) there were 45 utterances that belong to Code-switching (tag-switching) - The speaker uses this type to emphasize spoken sentences. The function of using Code-switching made by the students have classified 178 utterances, they are: a) reiterations function - to clarify or put pressure on what information has been. There were 28 (15\%) utterances; b) addressee specifications function - explain in more detail the talks being delivered. There were 52 (28\%) utterances; c) quotations function - to explain the previous words. There were 46 (25\%) utterances; d) personalization - to explain certain materials and provide further explanation of the next expression. There were 37 (20\%) utterances, and e) message qualification function - to explain something real and personal opinion of the speaker. There were 24 (12\%) utterances. It means that the students of English Education Department batch 2017 still made a lot of Code-switching during the classroom performances, where it indicates that the students' ability in speaking requires improvement, especially in a specific field such as Mathematics.

\section{REFERENCES}

[1] Ahmad, B.H., Jusoff, K., 2009. Teachers' CodeSwitching in Classroom Instrufollowingns for Low English Proficient Learners. English Lang. Teach. https://doi.org/10.553elt.v2n2p49

[2] the speaker'sn, J., Wardaugh, R., 1987.n to Sociolinguistics. Br. J. Sociol. https://doi.org/10.2307/590702

[3] Ammon, U., 2005. Sociolinguistics : an international handbook of the science of language and society = Sozindicating internationales Handbuch zur Wissenschaft von Sprache und Gesellschaft. Vol. 2, Handbücher zur Sprach- und Kommunikationswissenschaft,.

[4] Balukas, C., Koops, C., 2015. Spanish-English bilingual voice onset time in spontaneous code-switching. Int. J. Biling. https://doi.org/10.1177/1367006913516035

[5] Brennen, B.S., 2018. Doing Qualitative Research, in: Qualitative Research Methods for Media Studies. https://doi.org/10.4324/9781315435978-2

[6] Cacoullos, R.T., Travis, C.E., 2011. Testing convergence via code-switching: Priming and the structure of variable subject expression. Int. J. Biling. https://doi.org/10.1177/1367006910371025

[7] Clark, J., Yallop, C., 2006. An Introduction to Sociolinguistics Blackwell Textbooks in Linguistics, Religion. https://doi.org/10.1353/lan.2003.0268

[8] Creswell, J.W., 2012. Educational Research: Planning, Conducting and Evaluating Quantitative and Qualitative Research. Pearson, London.

[9] Creswell, J.W., 2009. Research design: Qualitative, quantitative, and mixed methods approaches (3rd ed). Res. Des. Qual. Quant. Mix. methods approaches. https://doi.org/10.1016/j.math.2010.09.003

[10] Crozier, G., Denzin, N., Lincoln, Y., 1994. Handbook of Qualitative Research. Br. J. Educ. Stud. https://doi.org/10.2307/3121684

[11] Dewaele, J.M., McCloskey, J., 2015. Attitudes towards foreign accents among adult multilingual language users. J. Multiling. Multicult. Dev. https://doi.org/10.1080/01434632.2014.909445

[12] González-Vilbazo, K., Bartlett, L., Downey, S., Ebert, S., Heil, J., Hoot, B., Koronkiewicz, B., Ramos, S., 2015. Methodological Considerations in CodeSwitching Research. Stud. Hisp. Lusoph. Linguist. https://doi.org/10.1515/shll-2013-1143

[13] Gort, M., 2012. Code-Switching Patterns in the WritingRelated Talk of Young Emergent Bilinguals. J. Lit. Res. https://doi.org/10.1177/1086296X11431626

[14] Henderson, R., 2011. Doing qualitative research: a practical handbook. Stud. Contin. Educ. https://doi.org/10.1080/0158037x.2011.609670

[15] Hlavac, J., 2011. Hesitation and monitoring phenomena in bilingual speech: A consequence of code-switching or a strategy to facilitate its incorporation? J. Pragmat. https://doi.org/10.1016/j.pragma.2011.09.008 
[16] Horasan, S., 2014. Code-switching in EFL classrooms and the perceptions of the students and teachers. Dil ve Dilbilimi Çalışmaları Derg. 10, 31-45. https://doi.org/10.17263/jlls.44110

[17] Iqbal, L., 2011. Linguistic features of code-switching: A study of Urdu/English bilingual teachers' classroom interactions. International Journal of Humanities and Social Science, 1, 188-194

[18] Isurin, L., Winford, D., Bot, K., 2009. Multidisciplinary approaches to code switching. Bijdragen. https://doi.org/10.1075/sibil.41

[19] Jingxia, L., 2010. Teachers' Code-Switching to the L1 in EFL Classroom. Open Appl. Linguist. J. https://doi.org/10.2174/1874913501003010010

[20] Kamisah Ariffin, Misyana Susanti Husin, 2011. Codeswitching and code-mixing of English and Bahasa Malaysia in content-based classrooms: Frequency and attitudes. Linguist. J.

[21] Lin, A., 2013. Classroom code-switching: Three decades of research. Appl. Linguist. Rev. https://doi.org/10.1515/applirev-2013-0009

[22] Mallinson, C., 2008. Review of Sociolinguistics/soziolinguistik: An international handbook of the science of language and society. Lang. Soc. https://doi.org/10.1017/S0047404508080585

[23] Modupeola, O.R., 2013. Code- Switching as a teaching strategy: Implication for English Language teaching and learning in a multilingual society. IOSR J. Humanit. Soc. Sci. 14, 92-94. https://doi.org/10.9790/19591439294

[24] Muldner, K., Hoiting, L., Sanger, L., Blumenfeld, L., Toivonen, I., 2019. The phonetics of code-switched vowels. Int. J. https://doi.org/10.1177/1367006917709093

[25] Musk, N., 2010. Code-switching and code-mixing in Welsh bilinguals' talk: Confirming or refuting the maintenance of language boundaries? Lang. Cult. Curric. https://doi.org/10.1080/07908318.2010.515993

[26] Naibaho, L., 2019. The effectiveness of independent learning method on students' speaking achievement at Christian University of Indonesia Jakarta. Asian EFL J.

[27] Naibaho, L., 2016a. Improving students' essay writing ability through consultancy: Prewriting protocol at Christian University of Indonesia.

[28] Naibaho, L., 2016b. Phonological Acquisition of A Child Suffering from Language Delay. Ijlecr- Int. J. Lang. Educ. Cult. Rev. 2, 33-42. https://doi.org/10.5151/cidi2017-060

[29] Olson, D., 2012. The phonetics of insertional codeswitching. Linguist. Approaches to Biling. https://doi.org/10.1075/lab.2.4.05ols

[30] Piccinini, P., Arvaniti, A., 2015. Voice onset time in Spanish-English spontaneous code-switching. J. Phon. https://doi.org/10.1016/j.wocn.2015.07.004

[31] Richards, J.C., Schmidt, R., 2010. Longman dictionary of language teaching \& applied linguistics, Proceedings of the 21st Asian Pacific Weed Science Society (APWSS) Conference, 2-6 October 2007, Colombo, Sri Lanka.

[32] Salzmann, Z., 2003. An Introduction to Sociolinguistics (review). Language (Baltim). https://doi.org/10.1353/lan.2003.0268

[33] Sampson, A., 2012. Learner code-switching versus english only. ELT J. https://doi.org/10.1093/elt/ccr067

[34] Scotton, C.M., 2010. Code switching as indexical of social negotiations, in: Codeswitching: Anthropological and Sociolinguistic Perspectives. https://doi.org/10.1515/9783110849615.151

[35] Scotton, C.M., Ury, W., 1977. Bilingual Strategies: The Social Functions of Code-Switching. Int. J. Soc. Lang. https://doi.org/10.1515/ijsl.1977.13.5

[36] Terrell, T.D., Brown, H.D., 1981. Principles of Language Learning and Teaching. Language (Baltim). https://doi.org/10.2307/414380

[37] Zabrodskaja, A., 2011. Multidisciplinary approaches to code switching. Int. J. Biling. Educ. Biling. https://doi.org/10.1080/13670050.2010.538258 